\title{
Nutrition of Nigerian Peasant Farmers, with Special Reference to the Effects of Vitamin A and Riboflavin Deficiency
}

\author{
By B. M. NICOL \\ Colonial Medical Service, Nigeria and Bida Native Authority Hospital, Bida, \\ Northern Nigeria
}

(Received 20 Fanuary 1949)

It is unnecessary to stress the difficulties which arise in the interpretation of data obtained from nutrition surveys. These have been considered by Sinclair (1944), Dann \& Darby (1945) and others. As knowledge increases, the standards by which the adequacy of diets is judged have to be altered; this is well exemplified by the frequent revision of the daily allowances recommended by the National Research Council of the United States of America. Further, there is no valid reason to expect that the requirements for optimum health and performance of one individual or one race will be the same as those of other individuals or races living under different environmental conditions. Kark, Aiton, Pease, Bean, Henderson, Johnson \& Richardson (1947) have shown that Gurkha soldiers, on a diet considerably 'inferior', by British and American standards, to that eaten by Canadian and American soldiers, were capable of physical performances significantly better than those of the white troops.

Difficulties arise in comparing the results of one survey with those of another. These are due to incomplete knowledge of the nutrient values of foodstuffs and of the degree to which nutrients are synthesized in the alimentary canal, to the variety of methods which have been employed in assessing food intake, and to the different clinical criteria used by different workers. In addition, pathological changes may occur from causes other than nutritional, and changes due to nutritional deficiencies may be conditioned by diseases which result in an inability on the part of the body to utilize nutrients. Dvsentery, intestinal infestations and hepatic cirrhosis are particularly prevalent in the tropics and, as McCarrison (1936) and Van Veen (1942) have pointed out, insufficient account of these factors has sometimes been taken in assessing the effects of nutritional deficiencies on clinical signs and symptoms.

Nutritional deficiencies are almost always multiple, and one may produce pathological changes which aggravate the effects of another. The liver damage which Himsworth and Glynn (Himsworth \& Glynn, I944; Glynn, I947; Himsworth, 1947) have shown to result from diets deficient in essential amino-acids is a case in point. It is not surprising, therefore, that much confusion has arisen when attempts were made to assess the specific effects of a deficiency of any one nutrient, particularly among native races living in the tropics.

Such confusion is shown by the varying views held as to the relative importance of deficiencies of vitamin A and riboflavin in the production of lesions of the eye and of the skin. During the course of the nutritional survey here reported it has been possible 
to compare the clinical features found in three groups of racially similar African peasant farmers, living within 200 miles of each other in the same climate, eating diets which, though composed of the same staple foodstuffs, were all deficient in riboflavin in varying amounts, but one of which contained ample supplies of carotene derived from red palm oil, whereas the other two were grossly deficient in this nutrient. It is hoped that a consideration of the physical status of these people may help to elucidate the clinical features resulting from deficiencies of vitamin $\mathrm{A}$ and riboflavin, with particular reference to changes in the skin and eyes.

\section{METHODS AND RESULTS}

\section{Scope of investigation}

A clinical and dietary survey was carried out during 1947 and 1948 in Niger Province, Northern Nigeria. This area lies between 9 and $12^{\circ}$ N., the climate being tropical, with a mean annual rainfall during the last ro years of between 40 and 60 in. The altitude varies between 500 and $1400 \mathrm{ft}$. above sea-level, but the mean relative humidity, a factor which possibly affects the condition and appearance of the skin (Aykroyd \& Rajagopal, 1936-7), does not vary significantly throughout the area.

Botanically the southern part of the area (Bida), in which lives one of the groups investigated, lies in the zone of Guinea Savannah, where red oil palms (Elaeis guineensis, Jacq.) are cultivated on stream banks. The central and northern districts (Kontagora and Zuru respectively) lie partly in Guinea Savannah and partly in Sudan Savannah, north of the limits of cultivation of the oil palm. It is this botanical fact, coupled with difficulties of transport and distribution of palm oil, which accounts for the high intake of carotene in Bida and the low intake in Kontagora and Zuru. In the last two districts shea-nut oil (Butyrospermum parkii) and small amounts of cow's butter replace red palm oil as cooking fat.

\section{Dietary studies}

\section{The families whose diets were investigated}

Three typical farming families, living in small hamlets between 4 and 8 miles from the nearest town or large market, were selected at random in each of the three areas. All food eaten by the adult occupants of the nine compounds was weighed and measured in detail for four periods of 7 days each, between March 1947 and March 1948, the periods being distributed throughout the year in accordance with the expected seasonal variation in availability of the staple foodstuffs. All individuals, over the estimated age of $\mathrm{I} 2$ years, were considered as adults, the numbers in the three families in each area being: Bida six males, eight females; Kontagora seven males, eight females; Zuru eight males, nine females; total forty-six. The weighing was done, under supervision, by a local nurse who had been specially trained for the purpose, on balances (not spring balances) to the nearest $\frac{1}{8} \mathrm{oz}$; t the conversion factor to grams was 28.35 .

\section{Estimation of intake of food and nutrients}

The method of calculating the energy and nutrient composition of individual diets from tables of representative values has been criticized recently by Bransby, Daubney \& King (1948-9), but Widdowson \& McCance (1943) found that the agreement, for 
average values, between direct analysis and calculation was sufficiently close to warrant the use of tables in dietary surveys.

In this study all foods were weighed and measured in bulk prior to cooking, and individual helpings were weighed after cooking. The amount of uncooked food ingested by each individual was calculated by proportion. For instance, if $5 \mathrm{lb}$. flour was boiled with water and the resulting porridge weighed I I lb. I oz., and an individual helping weighed $12 \mathrm{oz}$., the amount of dry flour eaten by this individual was taken to be $5 \cdot 2 \mathrm{oz}$. In the same way, the total volume of soup after boiling and the volume added to individual helpings was measured, and the amount of dry soup ingredients was calculated as a proportion of the weight of these ingredients prior to cooking. Food eaten in the fields outside the compounds was either weighed on the spot or its amount estimated by asking the farmers to bring back an equivalent amount, or the stones of mangoes and the kernels of shea nuts. The mean daily intake per caput for each group was calculated from the figures for each period of investigation, and from these data the energy and nutrient value of the diet was determined by using Platt's (1945 a) tables of representative values, certain additional values being taken from Nicholls's (1945) Tropical Nutrition.

\section{Consideration of the diets eaten}

The staple foodstuffs throughout all three areas are Guinea-corn (Sorghum vulgare Pers.) and bulrush millet (Penisetum typhoideum Rich.); cassava (Manihot utilissima Pohl.) and sweet potatoes (Ipomoea batatas Lam.) are used to some extent in Bida, but infrequently in Zuru and Kontagora, unless the grain crop fails. Certain other roots are cultivated to a lesser extent, and cow peas and green leaves in small amounts from many different plants are used in soups or made into cakes. Ground-nuts, although grown extensively, are almost all sold for cash. The only fruit available in quantity is the mango, for a short annual season of about 3 months. Animal protein is very scarce, the bulk of it being obtained from dried river fish.

The foodstuffs found in use during $1947^{-8}$ are shown in Table 1 . The botanical nomenclature is taken from Dalziel's (1916) Hausa Botanical Vocabulary.

During the year in question the rainfall was above average, and there was no shortage of food, judging by local standards.

\section{Preparation and cooking of foodstuffs}

The two main meals consist of Guinea-corn flour or millet flour made into porridge or dumplings, over which soup, containing vegetables, fish or meat, fat and salt, edible earths or 'ash juice', is poured. Subsidiary meals consist of boiled or baked roots or bambara nuts, cakes made by frying flour in oil, or sweets made from flour flavoured with juice from the fruit of gardenia or tamarind. Native beer, brewed from Guinea-corn or millet, is drunk in some quantity by the pagan farmers in Kontagora and Zuru, but is not used by the Moslems in Bida. A non-fermented infusion of tamarind and gardenia fruits is drunk occasionally in all areas.

The flour of Guinea-corn and millet is prepared by beating the grain (which is stored on the head), grinding and winnowing to remove the husk, and then pounding 
in a mortar to a coarse flour, which is then used for cooking. Winnowing is seldom employed after the initial grinding. The grain is not soaked prior to pounding unless

Table I. Average daily food consumption of peasant farmers based on a survey of adults in three districts of Nigeria

\begin{tabular}{|c|c|c|c|c|}
\hline Foodstuff & Botanical name & $\begin{array}{l}\text { Bida } \\
\text { (g.) }\end{array}$ & $\begin{array}{l}\text { Kontagora } \\
\text { (g.) }\end{array}$ & $\begin{array}{c}\text { Zuru } \\
\text { (g.) }\end{array}$ \\
\hline Guinea-corn & Sorghum vulgare Pers. & 417 & $5 \mathrm{II}$ & 765 \\
\hline Bulrush millet & Penisetum typhoideum Rich & 122 & 176 & 22 \\
\hline Maize: grain & Zea mays Linn. & . & 40 & . \\
\hline starch & & 5 & & \\
\hline cob, young & & 3 & 5 & 14 \\
\hline Rice, home-pounded & Oryza sativa Linn. & 0.3 & 0.3 & . \\
\hline Sweet potato & Ipomoea batatas Linn. & 156 & I4 & . \\
\hline Cassava tuber & Manihot utilissima Pohl. & 13 & 6 & 5 \\
\hline Yam & Dioscorea sativa Linn. & 7 & . & . \\
\hline Cocoyam & Colocasia antiquorum Schott. & . & 4 & 4 \\
\hline Kaffir potato & Plectanthus sp. & & . & 15 \\
\hline Cow pea & Vigna sinensis & 28 & 13 & 15 \\
\hline Locust-bean cake & Parkia filicoidea Welw. & 7 & 3 & I \\
\hline Red palm oil & Elaeis guineensis Jacq. & $2 \mathrm{I}$ & . & . \\
\hline Shea-nut oil & Butyrospermum parkii & . & 2 & $\mathbf{I}$ \\
\hline Shea butter & & . & I & . \\
\hline Cow's butter & & . & 2 & \\
\hline Milk & & . & 5 & 16 \\
\hline Beef & & 2 & I & . \\
\hline Mutton & & 2 & . & . \\
\hline Goat & & . & 2 & . \\
\hline Rat meat & & . & . & 2 \\
\hline Snake meat & & . & . & $0 \cdot 3$ \\
\hline Fish (fresh-water), dried & & 8 & I & I \\
\hline Okra: dried & Hibiscus esculentus Linn. & 2 & . & I \\
\hline fresh & & 9 & 4 & 2 \\
\hline Red sorrel: fresh & Hibiscus sabdariffa Linn. & I & . & I \\
\hline dried & & & & 5 \\
\hline Baobab leaf, dried & Adansonia digitata $\mathrm{B}$. Juss. & 4 & 6 & 16 \\
\hline Baobab fruit & & . & . & I \\
\hline Red pepper, dried & Capsicum frutescens $\mathrm{Bl}$. & 2 & 2 & 3 \\
\hline \multirow[t]{2}{*}{ Onions } & Allium cepa & 4 & I & . \\
\hline & A. fistulos & . & I & . \\
\hline Spinach, fresh & Amaranthus caudatus Linn. & . & $\mathrm{r}$ & . \\
\hline Jute leaf, fresh & Corchorus tridens Linn. & . & 0.3 & \\
\hline Shea-nut husk & Butyrospermum parkii & . & 58 & 45 \\
\hline Melon seeds & Citrullus vulgaris Schrad. & I & & . \\
\hline Gardenia fruit & Gardenia erubescens Stapf. & . & I & . \\
\hline Taura & Detarium senegalense Gmel. & I & I & \\
\hline Dates, dried & Phoenix dactylifera Linn. & & & . \\
\hline Mango & Mangifera indica Linn. & 179 & 75 & 45 \\
\hline Ground-nuts & Arachis hypogaea Linn. & 2 & & \\
\hline Bambara nuts & Voandzeia subterranea Thouars & 2 & $\mathrm{x}$ & \\
\hline Native beer (ml.) & & & 340 & 228 \\
\hline Saltpetre & & I & & I \\
\hline English salt & & 7 & 2 & 3 \\
\hline Sugar cane, stem & Saccharum officinarum Linn. & . & . & 6 \\
\hline Caterpillars & & 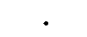 & . & 4 \\
\hline
\end{tabular}

it is very dry from prolonged storage, and water is not added to the mortar. The resultant flour contains a good proportion of bran. In calculating the nutrient content of Guinea-corn flour the values given by Platt (1945a) for 'straight-run meal' have 
been used. In making porridge or dumplings the flour is boiled for $\frac{1}{2}-\frac{3}{4} \mathrm{hr}$. in open pots, the amount of water added varying with the type of food to be prepared.

Roots are cooked by boiling in open pots for $\mathrm{I}-\mathrm{I} \frac{1}{2} \mathrm{hr}$., sweet potatoes in their skins, and cassava after peeling, and are eaten with oil, salt and peppers.

The vegetables, meat or fish, fat and condiments are boiled together in water, and the resultant soup is poured over the cooked grain, none of the water used in its preparation being wasted.

Table 2. Calculated daily nutrient intakes of Nigeria peasant farmers in three districts

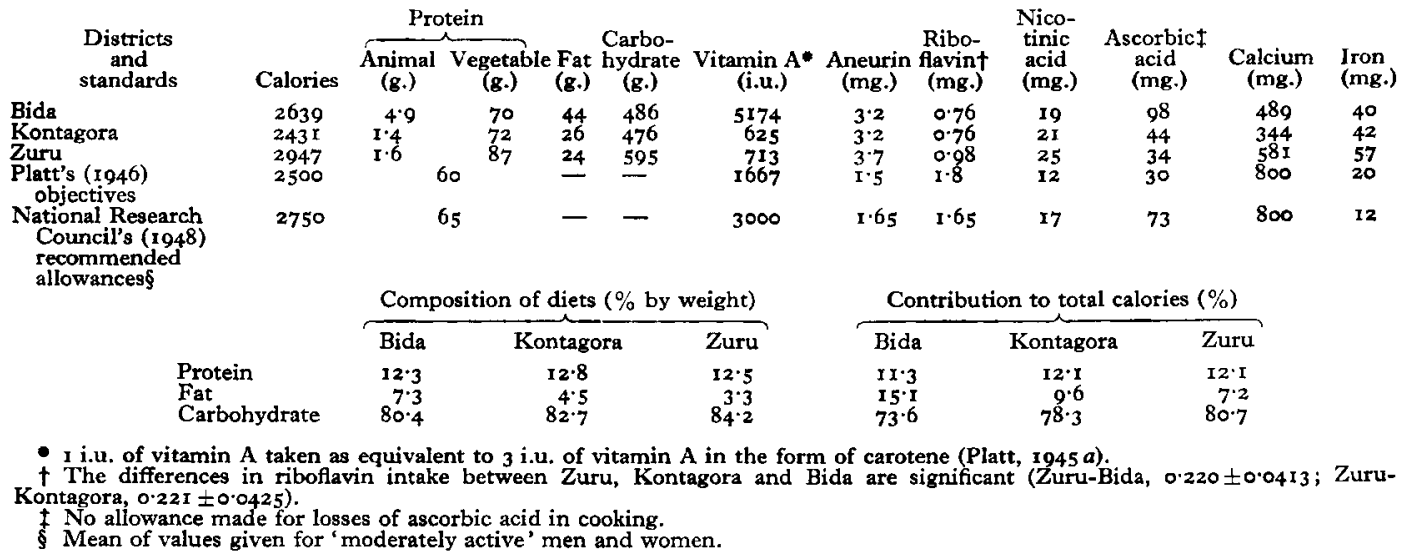

The only use of fermentation which was observed is in the preparation of a cake, used to flavour soups, made from the seeds of the locust-bean tree (Parkia filicoidea Welw.). The seeds are washed, boiled and soaked in water overnight, then pounded and spread in the sun for IO-12 hr. until 'they smell ready to be made into the cake'. This cake is eaten in small amounts, but constantly throughout the year. It probably contains significant, but unknown, amounts of the vitamin $B_{2}$ complex, and as a result the recorded mean daily intake of riboflavin for the year (Table 2) is probably slightly lower than the actual intake.

In the analysis of the diets ('Table 2) no allowance has been made for the destruction of nutrients during cooking, which is done, almost invariably, by boiling in open pots. Food is seldom kept hot for long periods before eating, but occasionally the 'unexpended portion' of a cooked meal is reheated the next day as a subsidiary meal. Soup is always finished with the meal for which it is prepared.

Nutritive value of the diets

The mean daily intakes of calories and nutrients, as calculated by the methods detailed above, are set out in Table 2. Comparison is made with the 'objectives' set by Platt (1946) for the nutrition of colonial peoples and with the 'allowances' recommended by the National Research Council (1948) for American citizens.

By Platt's standards it will be seen that the only deficiencies which occur in all three areas are of calcium and riboflavin. In Zuru and Kontagora the intake of vitamin A 
is very low. If an allowance of $67 \%$ is made for the destruction of ascorbic acid by cooking, the intake in two areas falls below the figure of $30 \mathrm{mg}$. recommended by Platt (1946) and by the Medical Research Council (1948) to cover all requirements for active life and inherent individual variability. When this allowance is made, however, the calculated intake in each area still remains above the 'minimal protective dose' of Io mg. found by the Medical Research Council to be necessary to prevent clinical scurvy. It is not considered probable that cooking destroys any other nutrient to a degree sufficient to convert the surpluses shown in Table 2 into deficits. As the flour used contains a high proportion of bran, the amount of calcium absorbed is undoubtedly reduced by the action of phytic acid to even lower levels than those shown in the table. The extent to which this occurs is unknown. The amount of calcium derived from water, edible earths and ash juice is negligible.

The total protein intake is more than that recommended by Platt, but, as the amount of animal protein ingested is small, and as over $80 \%$ of total protein is derived from two cereals only, it is extremely probable that deficiencies of essential amino-acids exist. The amount of fat $\left(7^{-15} \%\right.$ of the calories) supplied by the diets is lower than that usually considered adequate.

The following differences of nutrient intake from one area to another are noteworthy:

(1) The intake of vitamin A is very low in Kontagora and Zuru, but plentiful in Bida.

(2) The intake of riboflavin in Bida and Kontagora is only $75 \%$ of that in Zuru.

(3) The intake of fat in Bida is almost twice that in the other areas.

(4) The intake of protein is higher in Zuru than elsewhere.

These differences result from the ready availability of red palm oil in Bida, and from the fact that Guinea-corn is eaten in large quantities in Zuru but other millets and roots are little used, the Guinea-corn containing larger amounts of riboflavin and protein than bulrush millet and roots respectively.

\section{Clinical examination}

\section{Clinical studies}

Those individuals whose food was measured, and as many of the neighbouring farmers and their families as possible, were examined during the first 3 months of 1948 , this being the end of the dry season when work was slack after the harvest, and before the rains and next year's planting started. Unfortunately, this part of the investigation had to be curtailed, and fewer individuals were examined than was originally planned.

The clinical criteria used in the examinations are stated in Table 4. As far as possible the terminology used has been based on that described and illustrated by Platt (1945 $b$ ), and free reference has been made also to the paper by Sandstead \& Anderson (1947) on the criteria used by them in the clinical evaluation of nutritional status.

Particular care was taken in the examination of the liver and in recording clinical signs attributable to hepatic disease. Each individual was questioned about any previous history of jaundice or haematuria, schistosomiasis being by far the commonest cause of the latter symptom in this area.

Ehrlich's aldehyde test was carried out in each case, although little importance has been attached to a positive result in view of the high incidence of malaria among the 
population. The test was performed by adding eight drops of reagent to $5 \mathrm{ml}$. freshly voided urine, a red colour appearing within I min. at atmospheric temperature, or after heating in the flame of a spirit lamp, being regarded as positive, a pink colour being taken to indicate only a trace of urobilinogen. The reagent was made up by dissolving I g. of paradimethylaminobenzaldehyde in $50 \mathrm{ml}$. conc. $\mathrm{HCl}$ diluted with $5 \circ \mathrm{ml}$. distilled water.

Haemoglobin was estimated by Sahli's method, the haemoglobinometer being calibrated at $14 \mathrm{~g} . \mathrm{Hb} / \mathrm{roO} \mathrm{ml}$. blood. 'The instrument was checked in the United Kingdom, after the conclusion of the survey, against a Haldane Haemoglobinometer, taking $100 \%$ (Haldane) as corresponding to $13.8 \mathrm{~g} . / 100 \mathrm{ml}$. Thus the haemoglobin levels recorded in Table 5 do not conform to the new standards recently published by King, Gilchrist, Wootton, Donaldson, Sisson, Macfarlane, Jope, O’Brien, Peterson and Strangeways (1947).

With the object of ascertaining infant mortality rates, all mothers were questioned regarding the numbers of live children, stillbirths, miscarriages and abortions, and this was cross-checked with the husband and neighbours. The limited accuracy of figures obtained by this method will be readily understood by anyone who has worked in the tropics, but more accurate records were not available.

\section{Clinical findings}

The age and sex incidence of the three samples of the population are given in Table 3 .

The incidence of clinical abnormalities in the samples, and the criteria on which they were assessed, are given in Table 4 .

Table 3. Age and sex incidence of samples of population examined clinically in three districts in Nigeria

\begin{tabular}{|c|c|c|c|c|c|c|c|c|c|c|c|c|c|}
\hline \multirow[b]{2}{*}{ District } & \multicolumn{2}{|c|}{$\begin{array}{l}0-10 \\
\text { years }\end{array}$} & \multicolumn{2}{|c|}{$\begin{array}{l}\text { I I }-20 \\
\text { years }\end{array}$} & \multicolumn{2}{|c|}{$\begin{array}{l}21-30 \\
\text { years }\end{array}$} & \multicolumn{2}{|c|}{$\begin{array}{l}3^{\mathrm{I}-40} \\
\text { years }\end{array}$} & \multicolumn{2}{|c|}{$\begin{array}{c}4^{1-50} \\
\text { years }\end{array}$} & \multicolumn{2}{|c|}{$\begin{array}{c}\text { Over } 5^{\circ} \\
\text { years }\end{array}$} & \multirow[b]{2}{*}{ 'Total } \\
\hline & M. & F. & M. & F. & M. & F. & M. & F. & M. & F. & M. & F. & \\
\hline Bida & 4 & 4 & $\mathrm{rr}$ & 9 & I $\mathrm{Y}$ & 17 & 8 & 9 & 6 & 6 & 4 & 3 & 92 \\
\hline Kontagora & 8 & 9 & I 7 & 14 & 6 & 8 & 6 & I I & 2 & 5 & 4 & 3 & 93 \\
\hline Zuru & 6 & 7 & 13 & 7 & 8 & 7 & 6 & 8 & 6 & 4 & 4 & 3 & 79 \\
\hline
\end{tabular}

The general appearance of individuals was classified into three groups, good, fair and poor, upon clinical impressions derived from such factors as mental and physical alertness, general skeletal and muscular development, and any other features disclosed by clinical examination. It is emphasized that the figures presented in Table 5 , as a result of this classification, are based on impression rather than on a consideration of definite grading criteria, but the impressions were standardized as far as possible by constant reference to the physical and mental development of the male nurse, a local Kontagora man, who assisted with all the examinations. No considerable variation in general appearance between the three areas was found. 
Table 4. Clinical features: classification and incidence in three districts in Nigeria

\section{A. Skin}

Clinical features

Staring hair

Generalized xerosis

'Elephant skin'

Folliculosis

Nasolabial seborrhoea

Permanent gooseflesh

'Crackled' skin

Atrophic skin

Tropical ulcers and scars

B. Eyes

Bulbar conjunctiva and sclera

Corneal opacities

\section{Night-blindness}

Photophobia

Cataract

Bulbar conjunctiva: vascularity

C. Lips and tongue

Angular stomatitis

Colour changes in tongue

Atrophy of epithelium of tongue

'Pebbling' of filiform papillae

Fissuring of tongue

Indentations of tongue

D. Other signs

Calf tenderness

Famine oedema

Rachitic signs

Gingivitis

Dental caries, malocclusion and missing teeth

\section{Grade Criteria upon which features assessed}

Dull, straight or lax hair, with or without depigmentation

General dryness of skin without scaling

Dry scaly skin, with accentuated pattern

As in Grade 2, but with follicular hyperkeratosis

Thickening of skin over elbows and knees only

Thickening includes dorsum of feet and ankles

Marked thickening over feet and ankles

$A$ few prominent follicles on forearms and thighs

2 Numerous follicles on arms, thighs, buttocks

Accumulation of sebaceous matter at base of alae nasae

2 As in $I$, but involving chin and forehead

Areas on neck or trunk where all follicles show cutis anserina

Skin of legs dry, scaly and crackled

Skin of legs shiny, smooth and hairless

Active ulcers or healed scars on feet or ankles

Bida (92)* Kontagora (93)* Zuru(79)*

$(\%) \quad(\%)$

$(\%)$

12

20

0

50

8

0

55

12

47

28

24

9

71

50

32

Pigmentation of sclera in palpebral fissure

Thickening and wrinkling without dryness

Dryness of conjunctiva with some early corneal haziness

Frank xerophthalmia with or without ulcer

Superficial corneal opacity without dryness of bulbar conjunctiva

Present according to subject's own statement

Clinical observation of patient's complaint

Opacity of lens visible to naked eye

Abnormal injection, but of minor degree

Marked injection and redness

44

50

44
46
6

38

50

6

53

I I

50

$4 I$

47
8

22

60

6

Slight maceration, or scarring

Marked maceration with or without fissuring

Reddened and sore-looking

Magenta or lilac

Marginal atrophy only

Patchy atrophy

Bald and smooth

Enlargement and prominence of filiform papillae, esp. anterior

Longitudinal only

2 Longitudinal and transverse

Oedematous indentations of margins

Tenderness elicited by pressure on calf muscles by hand

No other obvious cause for oedema noted

Two or more of signs noted

Infective conditions of gums

Caries easily seen in one or more teeth

3
3
2
70
36


Table 5 also shows the incidence of disorders of the liver as revealed clinically, or suggested by a history of jaundice or haematuria, or by the presence of abnormal amounts of urobilinogen in the urine. The mean haemoglobin levels are also given. The results are about the same in each of the three districts.

No significant difference in sex incidence for any of the clinical signs was observed. The incidence of certain features was found to vary with age. Dry, staring and depigmented hair was more frequent in children below ro years of age; the incidence of thickening of the bulbar conjunctiva, pigmentation of the sclera, and gingivitis increased with age. Generalized xerosis, although frequent in all age groups in Kontagora and Zuru, was most often found in those under 20 years and over $5 \circ$ years.

\section{Table 5. General appearance of people examined, percentage incidence of disorders of the liver and mean haemoglobin levels in three districts in Nigeria}

No. examined

General appearance: good

fair

poor

Clinically demonstrable liver disease

Previous history of jaundice

Previous history of haematuria

Urobilinogenuria

Mean haemoglobin readings ( $\%$ )

Standard deviation

Standard error of mean

$\begin{array}{ccc}\text { Bida } & \text { Kontagora } & \text { Zuru } \\ 92 & 93 & 79 \\ 47 & 43 & 38 \\ 47 & 48 & 46 \\ 6 & 9 & 16 \\ 15 & 12 & 9 \\ 5 & 6 & 6 \\ 9 & 3 & 6 \\ 46 & 36 & 47 \\ 70 & 73 & 76 \\ 10.62 & 10 \cdot 90 & 11 \cdot 95 \\ \pm 1 \cdot 13 & \pm 1 \cdot 1 \mathrm{I} & \pm 1 \cdot 36\end{array}$

In view of the observed differences in the nutrient composition of the diets, the clinical features have been grouped into those more frequently found to occur in Kontagora and Zuru, where the supply of vitamin A was very low; those more frequently found in Bida and Kontagora, where the intake of riboflavin was significantly lower than in Zuru (see footnote to Table 2); and those found to occur with more or less equal frequency throughout all areas. This grouping is shown in Table 6. Two signs were found to vary significantly between areas, although they did not coincide with the above grouping. These were atrophy of lingual papillae, more often seen in Bida than in Kontagora and Zuru, and pebbling of the filiform papillae, most often encountered in Kontagora.

In view of the frequency with which evidence of disorders of the liver was found to occur, the cases showing the severer grades of clinical disorders were analysed in an attempt to determine whether they showed any correlation with hepatic disease (Table 7). It will be seen that of those with dry and staring hair, corneal opacities and night-blindness in Bida, where the vitamin A intake was adequate, a high percentage suffered from gross liver damage. The incidence of cirrhosis among those showing these signs in Kontagora and Zuru was also found to be high, and for certain infrequent clinical features, particularly corneal opacities, was so high as to make it doubtful whether vitamin A deficiency could be considered the primary cause of the lesions. Apart from these groups, the coincidence of liver damage with clinical signs was extremely variable. 
The high incidence of hepatic cirrhosis in this and other parts of tropical Africa is undoubtedly due, in large part, to dietary deficiencies. The exact nature of these deficiencies is still in doubt, although lack of first class protein and vitamins of the $\mathrm{B}_{2}$ group are believed to be important (Hughes, 1946; 'Trowell \& Muwazi, r945 $a, b$; Gillman \& Gillman, 1945; Waterlow, 1948; Nicol, 1948).

Table 6. Grouping, according to nutrient intakes, of clinical features observed in three districts in Nigeria

\begin{tabular}{|c|c|c|c|}
\hline & Bida & Kontagora & Zuru \\
\hline Mean intake of $\left\{\begin{array}{l}\text { Vitamin A (i.u.) } \\
\text { Riboflavin (mg.) }\end{array}\right.$ & $\begin{array}{l}5174 \\
0.76\end{array}$ & $\begin{array}{l}625 \\
0.76\end{array}$ & $\begin{array}{l}7 \mathrm{I} 3 \\
0.98\end{array}$ \\
\hline No. examined & 92 & 93 & 79 \\
\hline
\end{tabular}

Clinical features (percentage incidence)

Group I: roughly the same incidence in each district

$\begin{array}{lccc}\text { Folliculosis } & 67 & 64 & 70 \\ \text { Ulcers and scars of ulcers } & 50 & 44 & 49 \\ \text { Atrophic skin } & 73 & 72 & 75 \\ \text { Thickening of bulbar conjunctiva } & 39 & 34 & 30 \\ \text { Pigmentation of sclera } & 32 & 44 & 35 \\ \text { Photophobia } & 9 & 8 & \text { I I } \\ \text { Colour changes in tongue } & 49 & 54 & 50 \\ \text { Fissuring of tongue } & 29 & 35 & 38 \\ \text { Gingivitis } & 54 & 51 & 47\end{array}$

Group 2: more frequent in Kontagora and Zuru than in Bida

$\begin{array}{lcc}\text { Kontagora } & \begin{array}{c}\text { Kair dry and staring, achromotrichia } \\ \text { and Zuru }\end{array} & \begin{array}{c}\text { Bida } \\ \text { Herosis, grade 2 }\end{array} \\ \text { Xerou } & 47 & 0 \\ \text { Follicular hyperkeratosis } & 47 & 0 \\ \text { Elephant skin, grades 2 and } 3 & 7 & 0 \\ \text { 'Crackled' skin } & 37 & 9 \\ \text { Night-blindness } & 37 & 3 \\ \text { Corneal opacities } & 16 & 4\end{array}$

Group 3: more frequent in Bida and Kontagora than in Zuru

$\begin{array}{lcc} & \text { Bida and } & \\ \text { Kontagora } & \text { Zuru } \\ \text { Angular stomatitis } & 57 & 36 \\ \text { Nasolabial seborrhoea } & 70 & 43 \\ \text { Permanent gooseflesh } & 23 & 14 \\ \text { Injection of bulbar conjunctiva } & 57 & 43\end{array}$

Significance : $P<0.03$ for each of the clinical features considered in Groups 2 and 3, calculated from absolute observations.

\section{Other clinical observations relating to nutrition}

The infant-mortality rate is extremely high (Table 8), and the part which can be attributed to poor nutrition is considerable, judging by the clinical findings in hospital practice (Table 9).

Patients suffering from advanced pulmonary tuberculosis are very frequently encountered in hospitals and dispensaries throughout the districts, but it is impossible to assess the relative aetiological importance of poor nutrition and lack of natural resistance to the infection. 


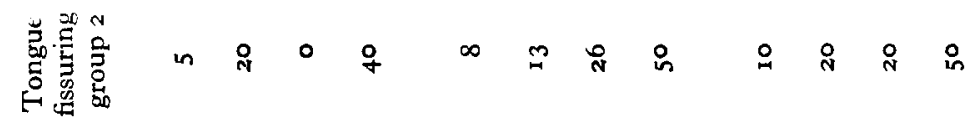
总密

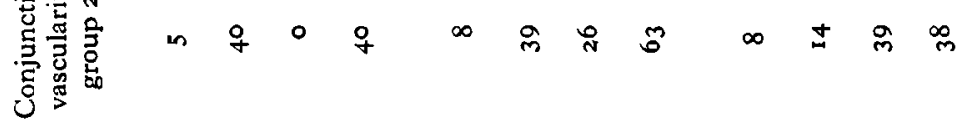

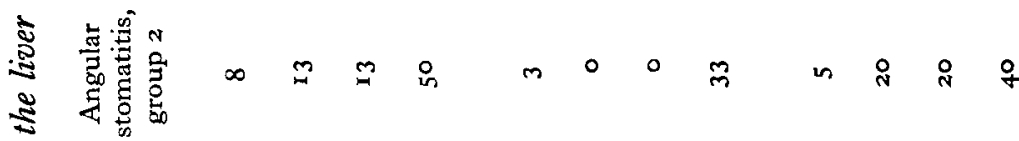

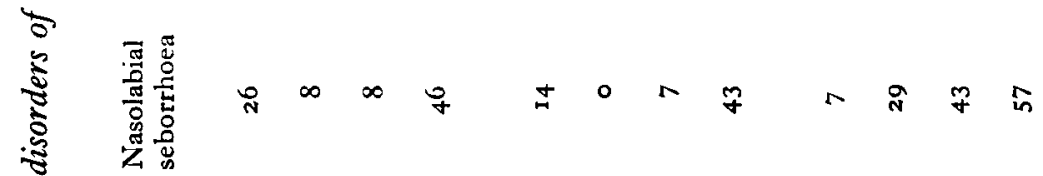

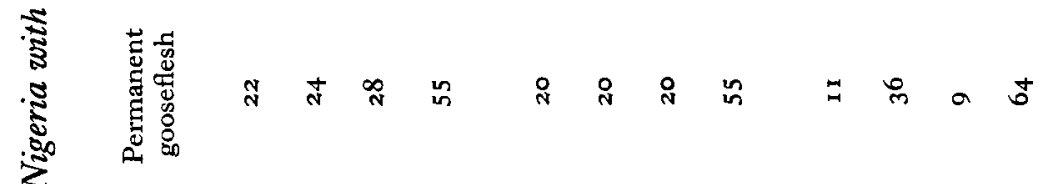

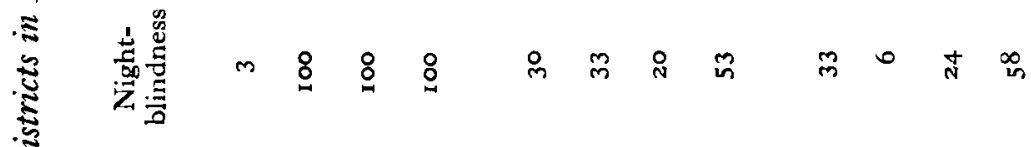

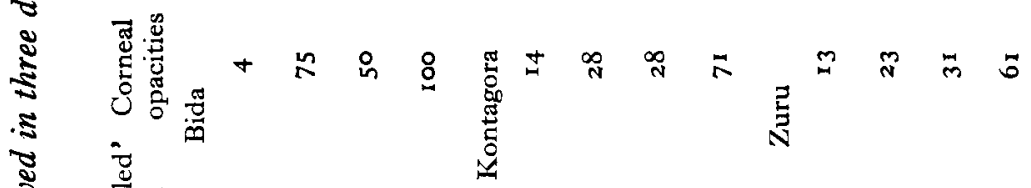

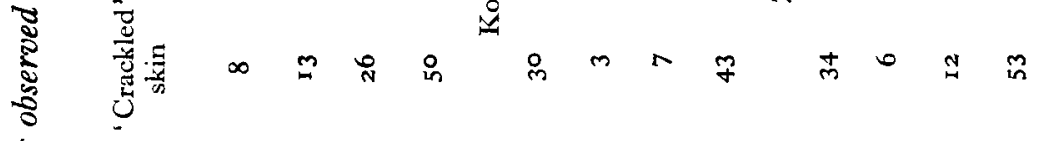
芯

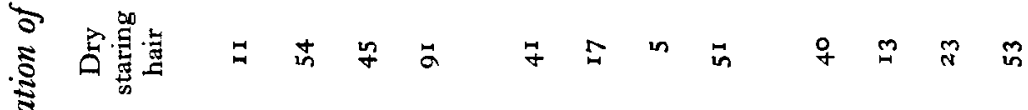
卷 立

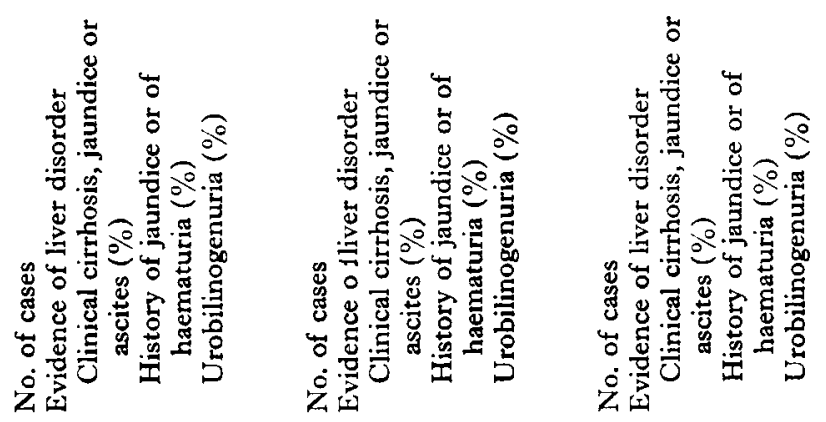


Table 8. Child mortality and failed pregnancies in three districts in Nigeria

\begin{tabular}{|c|c|c|c|c|c|c|c|}
\hline \multirow[b]{2}{*}{ District } & \multirow{2}{*}{$\begin{array}{l}\text { No. of } \\
\text { mothers }\end{array}$} & \multirow{2}{*}{$\begin{array}{l}\text { Children } \\
\text { alive }\end{array}$} & \multicolumn{3}{|c|}{ Children dying between birth and } & \multirow{2}{*}{$\begin{array}{c}\text { Infant- } \\
\text { mortality } \\
\text { rate* }\end{array}$} & \multirow{2}{*}{$\begin{array}{l}\text { Abortions, } \\
\text { miscarriages } \\
\text { and stillbirths }\end{array}$} \\
\hline & & & I year & 5 years & over 5 years & & \\
\hline Bida & $4 \mathrm{I}$ & 72 & 30 & 7 & 9 & 254 & 24 \\
\hline Kontagora & 30 & 87 & 55 & 8 & 7 & $35^{1}$ & 14 \\
\hline Zuru & 26 & 36 & 32 & 9 & 7 & 276 & 16 \\
\hline Total & 97 & I95 & 117 & 24 & 23 & 326 & 54 \\
\hline
\end{tabular}

Table 9. Deaths attributable to poor nutrition in children below 3 years of age admitted to Bida Hospital, Fanuary-October 1947

\begin{tabular}{|c|c|c|c|c|c|}
\hline \multicolumn{2}{|c|}{ Total no. admitted } & \multicolumn{2}{|c|}{$\begin{array}{l}\text { No. suffering from } \\
\text { malnutrition }\end{array}$} & \multicolumn{2}{|c|}{$\begin{array}{l}\text { Deaths attributed to } \\
\text { malnutrition }\end{array}$} \\
\hline & $I-3$ years & Under I year & $1-3$ years & Under I year & $I-3$ years \\
\hline 25 & 46 & 7 & I5 & 2 & 7 \\
\hline
\end{tabular}

Table 10. Percentage incidence of parasitic infestation in three districts in Nigeria

$\begin{array}{lccr}\text { (Macnamara, in 1945-6) } & \text { Bida } & \text { Kontagora } & \text { Zuru } \\ \text { No. examined } & 200 & 200 & 200 \\ \text { Ankylostomiasis } & 95 & 57 & 65 \\ \text { Ascariasis } & 0 & 6 & 5 \\ \text { S. Mansoni } & 0 & 5 & 4 \\ \text { S. Haematobium } & 50 & 70 & 39 \\ \text { Trypanosomiasis } & 15 & 0 & 0 \\ \text { (Nicol, in I947-8) } & & & \\ \text { Dracontiasis } & \text { Infrequent } & \text { Frequent } & \text { Frequent } \\ \text { Splenic index, children 2-10 years } & 20 & 15 & \text { I7 }\end{array}$

Figures showing the infestation rates encountered in this area are given in Table ro; I am indebted to $\mathrm{Dr} \mathrm{O}$. D. Macnamara for permission to use them.

Large groups of adults and children were weighed in each area, but heights were recorded in only a small number. The mean weights in the different areas showed no significant variation, and data obtained from the whole district are included in Fig. I. The numbers of individuals examined during this survey are too small to give satisfactory height and weight curves for comparative purposes. For interest, the weight of infants in Bida and Zuru are given in Fig. 2.

\section{DISCUSSION}

The impression which has been gained as a result of this survey is that gross pathological changes attributable to malnutrition are rarely encountered in this district of Northern Nigeria. Poor development and the minor clinical features which result from dietary deficiencies are seen very frequently, and produce physical incapacity of one form or another in roughly half of the population. The fact that Guinea-corn is the staple foodstuff, supplying adequate amounts of aneurin and nicotinic acid, is undoubtedly the reason why classical beriberi and pellagra do not occur. The value of red palm oil in the prevention of skin lesions is well demonstrated. Its carotene content is probably the most important factor in this respect, but it has been found that when 
Vol. 3

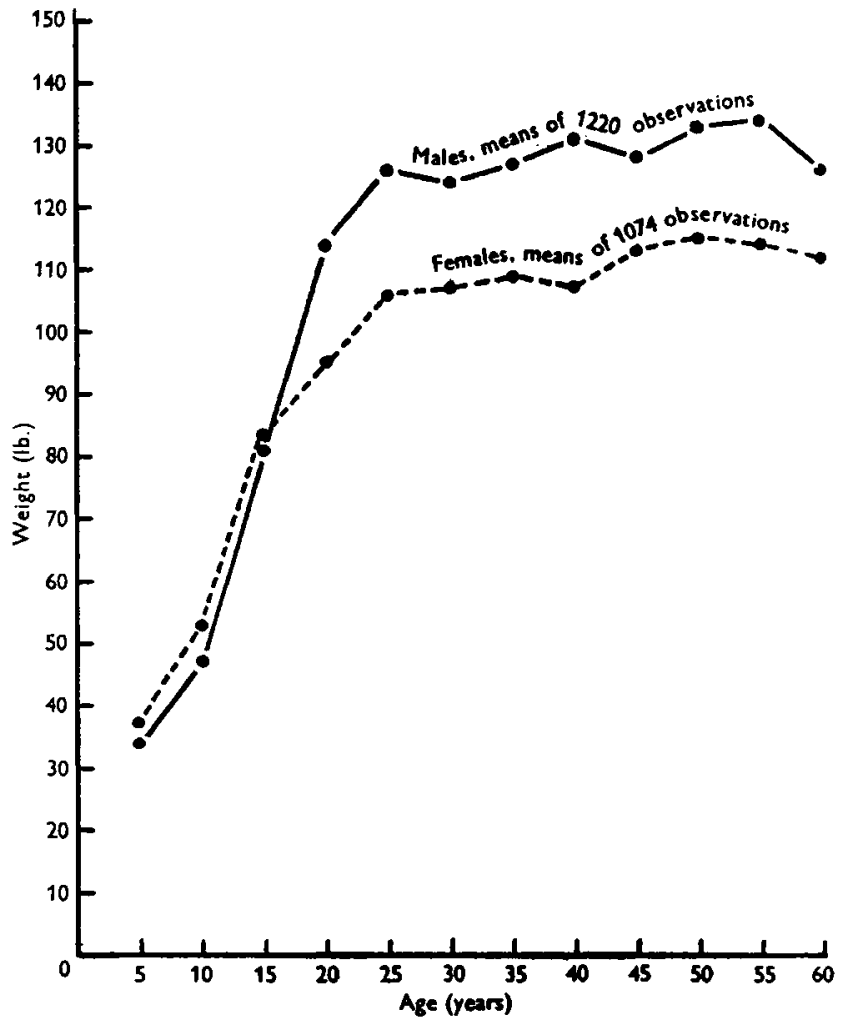

Fig. I. Mean weights of male and female Africans in Bida, Kontagora and Zuru.

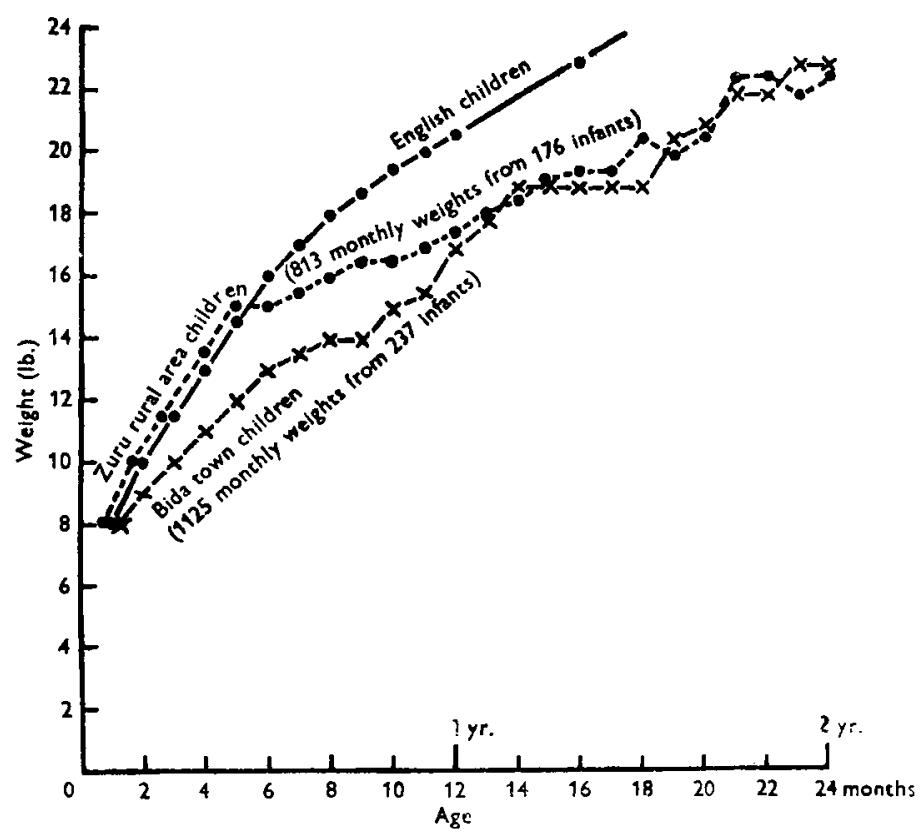

Fig. 2. Weights of African infants in Bida and Zuru. 
palm oil is readily available in an area, as in Bida, it is used more liberally in cooking than shea-nut oil or cow's butter. Thus it is possible that in Bida the higher intake of fats (and essential fatty acids), plays a part in the prevention of xerosis, 'elephant skin' and follicular hyperkeratosis. Deficiencies of fats and fatty acids have been suggested to be of importance in the aetiology of these conditions by Aykroyd \& Rajagopal (1936-7) and Hawes (1945).

Despite the fact that hepatic lesions are found with great frequency, and may be responsible for the development of signs of nutritional deficiency in some cases, it seems justifiable to conclude, with some degree of certainty, from the data presented in Table 6, that vitamin A deficiency results in dryness and depigmentation of hair, generalized xerosis, 'elephant skin', 'crackled' skin and night-blindness. It is equally justifiable to conclude that vitamin A deficiency does not play any part in the development of folliculosis, a finding which is considered in more detail below. Angular stomatitis, permanent gooseflesh, nasolabial seborrhoea and increased vascularity of the conjunctiva can be correlated with a low intake of riboflavin and are attributed to a deficiency of this nutrient. The role of vitamin A deficiency in the production of corneal opacity is considered below.

With regard to those signs that have been found with equal frequency in all areas, namely, tongue changes, folliculosis, gingivitis, proliferative eye lesions, cataract and tropical ulcers, it would be unwise to attribute them solely to riboflavin deficiency in view of their relatively constant incidence throughout the population. Lack of riboflavin in the diets may be of importance in their production, but multiple deficiencies of other nutrients, e.g. essential amino-acids and fatty acids, calcium and other unrecognized factors, may also play a part.

\section{Folliculosis}

The relationship of folliculosis to follicular hyperkeratosis and to vitamin A deficiency has been debated for a number of years (Frazier \& Hu, 193 I; Loewenthal, I933, I935; Nicholls, 1933, 1934, 1935; Pemberton, 1940; Aykroyd \& Rajagopal, 1936-7; Aykroyd \& Krishnan, 1936-7). The terminology used has been confusing. In this report 'folliculosis' indicates a simple enlargement or undue prominence of hair follicles, without obvious hyperkeratosis, which may occur on either a healthy-looking or a xerotic skin. 'Follicular hyperkeratosis' is here used to describe a marked thickening of hair follicles with projecting spiny plugs of keratinized material, occurring superimposed upon a generalized xerosis (the 'phrynoderma' of Nicholls). This differentiation has also been made by Frazier, $\mathrm{Hu} \& \mathrm{Chu}$ (1943) and Stannus (1945), and doubts expressed whether 'folliculosis' ('keratosis pilaris') was attributable to nutritional deficiency. Gross (1944) and Platt ( $1945 b)$ were guarded in attributing folliculosis to lack of any specific nutrient. Magee (1946) considered that folliculosis bears no apparent relation to the general nutritional state. On the other hand, the Council on Foods and Nutrition of the American Medical Association (1946) attributed 'a papular eruption... in the early stages like gooseflesh, but when fully developed presenting a picture of keratosis pilaris', to vitamin A deficiency, and Sinclair (1948-9) states that vitamin A deficiency is associated with some, but not all, cases of folliculosis. 
The evidence indicates that folliculosis, as defined above, is not epidemiologically associated with deficiency of vitamin A. It may be a sign of riboflavin deficiency, as suggested by Wolbach \& Bessey (1942), or of multiple deficiencies; it may result from lack of some unrecognized factor, or it may not be attributable in any way to nutritional causes. It has not been possible to correlate the incidence of folliculosis with that of other signs generally accepted as being the result of riboflavin or vitamin A deficiency (Table ir).

Table I I. Absence of correlation of folliculosis with signs of deficiency of vitamin $A$ and riboflavin in three districts in Nigeria

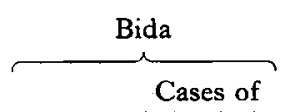

No. $\overbrace{\text { Percentage }}^{\text {folliculosis }}$

Clinical feature

Angular stomatitis:

Present

Absent

$\begin{array}{lll}51 & 37 & 72 \\ 41 & 25 & 61\end{array}$

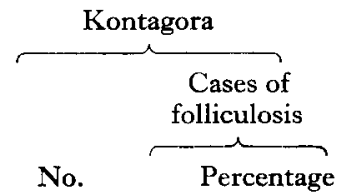

examined No. incidence

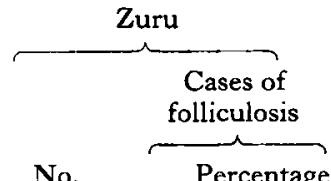

No. examined No. incidence

Xerosis:

Present

Absent

54

$\begin{array}{ll}36 & 67 \\ 23 & 60\end{array}$

29

50

22

76

39

60

$\begin{array}{ll}50-34 & 68\end{array}$

Hair dry and staring:

Present

Absent

$\begin{array}{rrr}18 & 13 & 72 \\ 74 & 50 & 68 \\ & & \\ & & \\ \text { I } & 7 & 64 \\ 81 & 55 & 68\end{array}$

$\begin{array}{rrr}84 & 57 & 68 \\ 4 & 2 & 50 \\ & & \\ 4 I & 26 & 63 \\ 52 & 32 & 61\end{array}$

$\begin{array}{rrr}76 & 54 & 71 \\ 3 & 2 & 67\end{array}$

$\begin{array}{lll}40 & 31 & 78\end{array}$

$\begin{array}{lll}39 & 24 & 62\end{array}$

\section{Proliferative eye changes}

'Thickening and pigmentation of the bulbar conjunctiva, Bitôt's spots and pigmentation of the sclera have been attributed by most workers to lack of vitamin A (Pillat, 1929a, $b$; Mori, I934; Nicholls, 1945; Aykroyd \& Rajagopal, 1936-7; Aykroyd \& Krishnan, 1936-7; Sandstead \& Osborne, 1948). Kark et al. (1947) were unable to associate proliferative eye changes of this nature with any specific nutritional factor. Response to vitamin A therapy is evidently variable. Spence (193I) and Meiklejohn (personal communication) say that Bitôt's spots clear up rapidly, whereas Métivier (194I) found them resistant to treatment. During the present survey Bitôt's spots were not encountered, even in those individuals suffering from a deficiency of vitamin A coexisting with severe hepatic damage. The incidence of thickening and pigmentation of the bulbar conjunctiva and sclera was uniformly distributed throughout the whole population, irrespective of diet, and increased with age, findings which lead to the conclusion that these signs may not be the result of nutritional deficiency. If lack of any nutrient is to be incriminated it is certainly not one of vitamin A, but possibly of riboflavin.

\section{Corneal opacities}

Prolonged severe deficiency of either vitamin A or riboflavin are reported to result, in both man and animals, in corneal opacities (Pillat, 1929 $a, b$; Lowenthal, 1933; Day, Darby \& Langston, 1937; Bessey \& Wolbach, 1939; Spies, 1939; Spies, Vilter \& Ashe, 
I939; Sydenstricker, Sebrell, Cleckley \& Kruse, I940; Métivier, I94I). These opacities due to nutritional causes are always anteriorly situated and usually superficial, in contrast to syphilitic keratitis, and are reported to respond to therapy with whichever vitamin is deficient. From the literature it would appear that thickening and dryness of the conjunctiva is a more frequent concomitant of corneal opacity due to vitamin A deficiency than of that due to riboflavin deficiency, and there seems to be little doubt that fully developed xerophthalmia is due to lack of the former.

In view of the combination of vitamin $A$ and riboflavin deficiencies, and of the high incidence of hepatic cirrhosis found in this investigation among the cases presenting corneal opacity, it is not possible to say whether deficiency of either vitamin is the primary cause of this lesion. A high incidence of liver disease was also found among those individuals who complained of night-blindness. This association of hepatic cirrhosis with keratitis and keratomalacia has long been recognized, and Weiss (I873) gave it the name 'ophthalmia hepatica'.

\section{Cataract}

Sydenstricker et al. (1940) and El-Sadr (1939) believe that riboflavin deficiency is a factor in the development of certain cases of cataract, a view with which the findings reported here are not inconsistent.

\section{Tongue}

Certain morphological changes in the tongue have been attributed either to riboflavin or nicotinic acid deficiency. The Council on Foods and Nutrition of the American Medical Association (1946) state that oedema, a beefy scarlet tongue with hypertrophy of papillae going on to atrophy, are characteristic of nicotinic acid deficiency. Spies (1939) described the tongue as being red, swollen, smooth and indented as a result of lack of nicotinic acid. Stannus had described this type of tongue in pellagrins as long ago as I912 (Stannus, I9I2, I944). Jolliffe (1939) has reported that the tongue in riboflavin deficiency is clean, purple, red or magenta, frequently fissured and with flattened or mushroom-shaped papillae, a description with which Sydenstricker $e t$ al. (1940) agree. Red, sore-looking tongues were more often seen during this survey than magenta-coloured ones. Patchy atrophy and hypertrophy were seen occurring together, and generalized 'pebbling' of filiform papillae, without coexistent atrophy, was frequently observed. Baldness of the tongue was rarely seen. It is concluded, therefore, that all the signs which have been attributed to nicotinic acid deficiency can appear with some frequency in a population whose diet contains this vitamin in amounts considered adequate, but which is deficient of riboflavin. Papillary atrophy was significantly more frequent in Bida than in Zuru, the calculated daily intakes of nicotinic acid in each area being 19 and $25 \mathrm{mg}$. respectively. These amounts are more than adequate by the standards quoted above, and force the conclusion that riboflavin is of more importance than nicotinic acid in the prevention of morphological changes in the tongue of the character discussed. 


\section{Other signs}

Manifestations of ascorbic acid deficiency were not encountered, in spite of the low actual intake which is probable in Zuru and Kontagora. Perifollicular haemorrhages were not seen in association with follicular hyperkeratosis, and the gingivitis, which was of frequent occurrence, was infective in type and often associated with dental caries. Magee (1946) does not think that gingivitis is of help in the diagnosis of nutritional deficiency.

Lesions of the central nervous system and peripheral neuritis were not found. This is of interest in relation to the incidence or tropical ulcer. A modern concept of the aetiology of this condition is that vasospasm due to sympathetic overactivity results from a low intake of vitamin B complex. The relatively poor vascular supply to the skin of the distal part of the lower extremity, with its abundant nerve supply, renders this area particularly prone to the development of chroniculcers. The use of vasodilator drugs, sympathectomy and extradural sympathetic block have been claimed to be of value in therapy (Ransford, 1948). In view of the adequate intake of nicotinic acid and aneurin, and the absence of signs of central or peripheral nervous involvement, it seems unlikely that such a mechanism is responsible for the high incidence of ulcers in this population.

Lesions of the thyroid gland were not encountered.

\section{SUMMARY}

I. An account is given of a nutrition survey carried out in Northern Nigeria in 1947 and 1948 .

2. The methods employed to determine the nutrient intake and nutritional status of the population are described, and the findings are presented.

3. From the data obtained the following conclusions are drawn:

(a) Vitamin A deficiency results in dry and staring hair and hypochromotrichia, generalized xerosis and follicular hyperkeratosis, 'elephant skin; 'crackled' skin and night-blindness.

(b) Deficiency of riboflavin results in angular stomatitis, permanent gooseflesh, nasolabial seborrhoea, and increased vascularity of the conjunctiva.

(c) Folliculosis of the skin and proliferative lesions of the bulbar conjunctiva are not due to deficiency of vitamin A, but are more likely to follow a prolonged low intake of riboflavin, if, indeed, they are in any way attributable to malnutrition.

4. In view of the frequent association of corneal opacity with signs of gross liver damage, it was impossible to decide whether these opacities are due to lack of vitamin A, riboflavin or to a combined deficiency of both.

5. In spite of an apparently adequate supply of nicotinic acid, morphological changes in the tongue customarily attributed to nicotinic acid deficiency were encountered frequently.

6. Certain other clinical features are discussed.

I am grateful to the Director of Medical Services, Nigeria, for permission to publish this paper, and I wish to thank Dr A. P. Meiklejohn of the Department of Medicine, 
University of Edinburgh, for advice and help. I acknowledge assistance with the statistical examination of the figures from Dr B. A. Woolf, Department of Public Health and Social Medicine, University of Edinburgh. I also wish to thank Dr R. Passmore, of the same department, for helpful criticism.

Mallam Abubakar Zukogi, Bida, and Mallam Isa Likita, Kontagora, rendered valuable assistance.

\section{REFERENCES}

American Medical Association, Council on Foods and Nutrition (1946). F. Amer. med. Ass. I3r, 666.

Aykroyd, W. R. \& Rajagopal, K. (1936-7). Indian Y. med. Res. 24, 419.

Aykroyd, W. R. \& Krishnan, B. G. (1936-7). Indian F. med. Res. 24, 707.

Bessey, O. A. \& Wolbach, S. B. (1939). F. exp. Med. 69, I.

Bransby, E. R., Daubney, C. G. \& King, J. (1948-9). Brit. F. Nutrit. 2, 89.

Dalziel, J. M. (1916). A Hausa Botanical Vocabulary. London: Unwin.

Dann, W. J. \& Darby, W. J. (1945). Physiol. Rev. 25, 326.

Day, P. L., Darby, W. J. \& Langston, W. C. (1937). F. Nutrit. 13, 389.

El-Sadr, M. M. (1939). Chem. $\mathscr{F}^{\circ}$ Ind. 58, 1020.

Frazier, C. N. \& Hu, C. (1931). Arch. intern. Med. 48, 507.

Frazier, C. N., Hu, C. \& Chu, F. (1943). Arch. Derm. Syph., N.Y., 48, I.

Gillman, T. \& Gillman, J. (1945). F. Amer. med. Ass. 129, I 2.

Glynn, L. E. (1947). Nutr. Abstr. Rev. 16, 75 I.

Gross, P. (1 944). Clinics, 3, 789 .

Hawes, R. B. (1945). Proc. R. Soc. Med. 38, 342.

Himsworth, H. P. (1947). Lectures on the Liver and its Diseases. Oxford: Blackwell.

Himsworth, H. P. \& Glynn, L. E. (1944). F. Path. Bact. 56, 297.

Hughes, W. (1946). Trans. R. Soc. trop. Med. Hyg. 39, 437.

Jolliffe, N. (1939). New Engl. F. Med. 22x, 921 .

Kark, R. M., Aiton, H. F., Pease, E. D., Bean, W. B., Henderson, C. R., Johnson, R. E. \& Richardson, L. M. (1947). Medicine, Baltimore, 26, 1 .

King, E. J., Gilchrist, M., Wootton, I. D. P., Donaldson, R., Sisson, R. B., Macfarlane, R. G., Jope, H. M., O'Brien, J. R. P., Peterson, J. M. \& Strangeways, D. H. (1947). Lancet, 253, 789.

Loewenthal, L. J. A. (1933). Arch. Derm. Syph., N. Y., 28, 700.

Loewenthal, L. J. A. (1935). Ann. trop. Med. Parasit. 29, 349.

Magee, H. E. (1946). Brit. med. F. i, 475.

McCarrison, R. (1936). Cantor Lectures. London: Royal Society of Arts.

Medical Research Council (1948). Lancet, 255, 853.

Métivier, V. M. (194I). Amer. F. Ophthal. 24, I264.

Mori, S. (1934). F. orient. Med. 2, I03 (quoted by Frazier, Hu \& Chu, 1943).

National Research Council (1948). Nutrit. Rev. 6, 3 19.

Nicholls, L. (1933). Indian med. Gaz. 68, 68 I.

Nicholls, L. (1934). Indian med. Gaz. 69, 241.

Nicholls, L. (1935). Indian med. Gaz. 7o, 14.

Nicholls, L. (1945). Tropical Nutrition, 2nd ed. London: Baillière, Tindall and Cox.

Nicol, B. M. (1948). (In the Press).

Pemberton, J. (1940). Lancet, 238, $87 \mathrm{I}$.

Pillat, A. (1929a). Arch. Ophthal., Chicago, 2, 256.

Pillat, A. (1929b). Arch. Ophthal., Chicago, 2, 399.

Platt, B. S. (1945a). Spec. Rep. Ser. med. Res. Coun., Lond., no. 253.

Platt, B. S. (1945b). Brit. med. Bull. 3, 179.

Platt, B. S. (1946). Trans. R. Soc. trop. Med. Hyg. 40, 379.

Ransford, O. N. (1 948). Trans. R. Soc. trop. Med. Hyg. 42, 267.

Sandstead, H. R. \& Anderson, R. K. (1947). Publ. Hlth Rep., Wash., 62, 1073.

Sandstead, H. R. \& Osborne, E. S. (x948). Amer. F. publ. Hlth, 38, 361.

Sinclair, H. M. (1944). Amer. F. publ. Hlth, 34, 828.

Sinclair, H. M. (1948-9). Brit. $\mathcal{F}$. Nutrit. 2, 161.

Spence, J. C. (1931). Arch. Dis. Childh. 6, I7.

Spies, T. D. ( 1939). Amer. F. med. Sci. 198, 40.

Spies, T. D., Vilter, R. W. \& Ashe, W. F. (1939). F. Amer. med. Ass. 113. 931.

Stannus, H. S. (1912). Trans. R. Soc, trop. Med. Hyg. 5, I I 2. 
Stannus, H. S. (1944). Brit. med. F. ii, 103, 140.

Stannus, H. S. (1945). Proc. R. Soc. Med. 38, 337.

Sydenstricker, V. P., Sebrell, W. H., Cleckley, H. M. \& Kruse, H. D. (1940). F. Amer. med. Ass. II4, 2437.

Trowell, H. C. \& Muwazi, E. M. K. (1945a). Trans. R. Soc. trop. Med. Hyg. 39, 229.

'Trowell, H. C. \& Muwazi, E. M. K. (1945b). Arch. Dis. Childh. 20, i 10.

Van Veen, A. G. (1942). Ann. Rev. Biochem. II, 391.

Waterlow, J. C. (1948). Spec. Rep. Ser. med. Res. Coun., Lond., no. 263.

Weiss (1873). Berl. klin. Wschr. p. 232 (quoted by Pillat).

Widdowson, E. M. \& McCance, R. A. (1943). Lancet, 244, 230.

Wolbach, S. B. \& Bessey, O. A. (1942). Physiol. Rev. 233.

\title{
A Photoelectric Spectrophotometer Suitable for the Measure- ment of Vitamin A by the Antimony-Trichloride Reaction
}

\author{
BY S. Y. THOMPSON \\ National Institute for Research in Dairying, University of Reading
}

(Received 29 Fanuary 1949)

The measurement by visual methods of the fleeting blue colour of vitamin $A$ in the antimony-trichloride reaction presents considerable difficulties which can be largely overcome by the use of photoelectric methods with corresponding increase in accuracy.

The photoelectric spectrophotometer now described was constructed in I94I when no comparable instrument of this type was commercially available here. It has been in continuous use in this laboratory ever since (Thompson, Kon \& Mawson, 1942; Kon, Mawson \& Thompson, I944; Mattick, Hiscox, Crossley, Lea, Findlay, Smith, Thompson, Kon \& Egdell, I945; Blaxter, Kon \& Thompson, I946; Braude, Kon \& Thompson, 1946; Ganguly, Kon \& Thompson, I947; Thompson, Ganguly \& Kon, I947; Braude, Henry, Kon \& Thompson, I947; Braude, Coates, Henry, Kon, Rowland, Thompson \& Walker, r947; Aschaffenburg, Bartlett, Kon, Terry, Thompson, Walker, Briggs \& Cotchin, I948; Thompson, Ganguly \& Kon, I949). Apart, however, from a brief mention at a meeting of the Biochemical Society (Thompson, 1942) no description of the apparatus has so far been published and for this reason it is now reported here.

\section{EXPERIMENTAL}

\section{General}

The instrument is generally applicable to absorption measurements in the visible spectrum. It is of the direct-reading type and uses a monochromator which, for photoelectric spectrophotometry, has many advantages. If the spectral band isolated is sufficiently narrow, the readings obtained are in terms of universally applicable absolute units, so that results can be expressed without reference to standard solutions or calibration curves. Further, the instrument can be used for identification of coloured substances by measurement of the shape of their absorption curves and of the position of the absorption maxima.

The direct reading, instead of the null-point, method was chosen, as the instrument 